Tarih Okulu Dergisi (TOD)

Journal of History School (JOHS)

Aralık 2021

December 2021

Yıl 14, Sayı LV, ss.3960-3981.

Year 14, Issue LV, pp.3960-3981.

DOI No: http://dx.doi.org/10.29228/Joh.54120

Authenticity process is conducted by

Makale Türü: Araştırma makalesi

Geliş Tarihi: 08-11-2021

Kabul Tarihi: 13-12-2021

On-line Yayın: 30-12-2021

Article Type: Research article

Submitted: 08-11-2021

Accepted: 13-12-2021

Published Online: 30-12-2021

Atıf Bilgisi / Reference Information

Akkaş, E., Akkuş, M. \& Emsen Ö.S. (2021). Investigating the Relationship Between Socio-Economic Characteristics and Duration of Depression Treatment in Patients Diagnosed with Depression. Journal of History School, 55, 39603981.

\title{
INVESTIGATING THE RELATIONSHIP BETWEEN SOCIO- ECONOMIC CHARACTERISTICS AND DURATION OF DEPRESSION TREATMENT IN PATIENTS DIAGNOSED WITH DEPRESSION ${ }^{1}$
}

\author{
Elif AKKAŞ ${ }^{2}$, Mustafa AKKUŞ ${ }^{3}$ \& Ömer Selçuk EMSEN ${ }^{4}$
}

\begin{abstract}
The purpose of this study was to investigate the relationship between socio-economic characteristics and period of depression treatment in patients diagnosed with depression in Erzincan. Face-to-face questionnaire was performed to the patients diagnosed with depression in the Psychiatry Clinic of Erzincan Binali Yıldırım University Mengücek Gazi Training and Research Hospital. This questionnaire was performed to 311 patients diagnosed with depression. The analysis was performed using ordered probit model. For the questionnaire, 26.12.2019 dated and 12/18 protocol numbered "Human Research Ethics Committee" approval was obtained from Erzincan Binali Yıldırım University. The duration for the treatment was shorter in female patients treated for depression for more

\footnotetext{
${ }^{1}$ Makale yazımı yazar etki oranı: 1.yazar: \%40, 2. yazar: \%30, 3. yazar: \%30. Bu Makalenin etik kurul onayı Erzincan Binali Yıldırım Üniversitesi'nde İnsan Araştırmaları Etik Kurulu'nun 26.12.2019 tarih ve 12/18 sayı ve toplantı numarası ile alınmıştır.

${ }^{2}$ Arş. Gör., Erzincan Binaki Yıldırım Üniversitesi, İktisadi ve İdari Bilimler Fakültesi, Sağlık Yönetimi Bölümü, Sağlık Ekonomisi ve Politikaları Ana Bilim Dalı, elif.akkas@erzincan.edu.tr, 0000-0002-9555-7340.

${ }^{3}$ Dr.Öğr.Ü., Erzincan Binali Yıldırım Üniversitesi Mengücek Gazi Eğitim ve Araştırma Hastanesi Ruh Sağlığı ve Hastalıkları (Psikiyatri), drmustafaakkus@gmail.com, 0000-0002-5674-6632.

${ }^{4}$ Prof.Dr., Atatürk Üniversitesi İktisadi ve İdari Bilimler Fakültesi İktisat Bölümü, osemsen@atauni.edu.tr, 0000-0002-1809-0513.
} 
Investigating The Relationship Between Socio-Economic Characteristics...

than 3 years rather than males. The duration of treatment for depression decreased as the level of education increased. The patients with higher monthly income had longer treatment periods rather than the ones with lower monthly income. The duration of treatment was shorter in patients with extended families. The duration of treatment was shorter in patients who had no assets. The period for depression treatment was longer in patients who worked for 21 years and more rather than the ones who had never been employed. These findings were totally opposite for the treatment period of 1 year and less. Socioeconomic factors were correlated with periods of depression. However, this relationship differed according to the duration of depression.

Keywords: Depression, Mental Health, Socio-Economic Characteristics.

\section{Depresyon Tanılı Hastalarda Sosyo-Ekonomik Özellikler ile Depresyon Tedavi Süresi Arasındaki İlişsinin İncelenmesi}

\section{$\ddot{O}_{z}$}

$\mathrm{Bu}$ çalışmanın amacı, Erzincan'daki depresyon tanılı hastalarda sosyo-ekonomik özellikler ile depresyon tedavi süresi arasındaki ilişkiyi değerlendirmektir. Erzincan Binali Yıldırım Üniversitesi Mengücek Gazi Eğitim ve Araştırma Hastanesi Psikiyatri Polikliniğinde depresyon tanısı konulan hastalara yüz yüze anket uygulanmıştır. Söz konusu anket çalışması 311 depresyon hastasıyla gerçekleştirilmiştir. Sıralı probit model ile analiz yapılmıştır. Anket uygulaması için Erzincan Binali Yıldırım Üniversitesi "İnsan Araştırmaları Etik Kurulu'ndan" 26.12.2019 tarih ve 12/18 protokol numarası ile izin alınmıştır. 3 yıldan fazla süren depresyon tedavisi gören hastalarda kadınların tedavi görme süreleri erkeklerden kısadır. Eğitim seviyesi arttıkça depresyon tedavi süresi kısalmaktadır. Aylık geliri yüksek olan hastaların düşük olan hastalara göre tedavi süreleri daha uzundur. Geniş ailelere sahip hastalarda tedavi süresi kısalmaktadır. Malvarlığı olmayan hastalarda tedavi süresi daha kısadır. 21 yıl ve daha fazla çalıșan hastalarda depresyon tedavi süreleri hiç çalışmamış hastalara göre daha uzundur. $\mathrm{Bu}$ bulgular tedavi süresi 1yıl ve daha kısa olan sürelerde tam tersidir. Sosyoekonomik faktörler depresyon süreleri ile ilişkilidir. Ancak bu ilişki depresyon sürelerine göre farkl1lık gösterir.

Anahtar Kelimeler: Depresyon, Ruh Sağlı̆ğ, Sosyo-Ekonomik Özellikler.

\section{INTRODUCTION}

Depression is a remarkable public health problem beyond societies and countries. It is the leading cause of disability all around the world, and the global burden of depression has been increasing (Freeman et al., 2006, p.1-2). According to the Global Burden of Disease 2010 research, 400 million people worldwide 
have been estimated to be suffered from depression (including dysthymia) (Allen et al., 2014, p.92-393). It is estimated that $26 \%$ of adults (approximately 58 million) have suffered from diagnosable mental disorder at any given year and approximately 15 million adults have major depressive disorder in the USA. Total societal cost of such mental health disorders is at a remarkable level with estimates up to $\$ 200$ billion per year for the USA (Frijters et al., 2014, p.1058).

The effects of depression can be long-lasting or recurrent and are possible to significantly affect individuals' ability of functioning and maintaining a rewarding life (WHO, 2021). Depressive disorders are very common in the society, and the impact on the mood or emotions of the affected individuals, the severity (mild to severe) and duration of symptoms can vary from months to years (WHO, 2017, p.5).

After providing adjustments for initial severity of symptoms using ECA dataset for the permanence of depression, no significant relationship has been found in terms of socio-economic status score, low level of education, or permanence. The data obtained from the Stirling County study in Canada have revealed a tendency for lower socio-economic status associated with both the onset and permanence of depression or anxiety. A meta-analysis of longitudinal studies has indicated a significant relationship between socio-economic indicators and both onset and permanence, but the effect of permanence is higher (Skapinakis et al., 2006, p.114-115).

Socioeconomic status is a well-known determinant for health status. In developed countries, the lower individuals' socioeconomic status, the worse their health. Even in the most affluent countries, the individuals in lower socioeconomic status groups have significantly shorter life expectancies and higher morbidity rather than the ones from higher socio-economic status groups. Low socio-economic status is associated with a higher risk of coronary heart disease, hypertension, diabetes and other non-infectious diseases in developed countries such as the UK. Various factors contribute upon this, but misbehaviors related to health and psycho-social difficulties among the most prominent factors are the leading factors (Lazzarino et al., 2014, s.1). It has been increasingly known that social and economic conditions of individuals affect their health. These social determinants include the conditions in which people are born, live, work and age (Allen et al., 2014, p.392-393).

Previous cross-sectional studies have revealed that individuals in lower socio-economic groups have increased prevalence of common mental disorders. Psychiatric disorders often have a chronic course, and patients in lower socioeconomic groups are more likely to have a worse prognosis rather than an 
Investigating The Relationship Between Socio-Economic Characteristics...

increase at the risk of a new disorder attack. Furthermore, other studies have suggested that low socioeconomic status is possible to be a risk factor for the development of a new episode (Skapinakis et al., 2006, p.109).

The SES element beset by increasing national and international inequalities in income, education and wealth and socio-economic status (SES) has become the focus point as a major determinant of depression. Accordingly, the role of SES in depression is an important theme. (Freeman et al., 2006, p.1-2). A recent meta-analysis has revealed that the effect of low socio-economic status upon depression is higher rather than the onset for the permanence of episode (Lorant et al., 2007, p.293). Socio-economic status generally has a higher effect upon the permanence of depression rather than onset (Butterworth et al., 2009, p.229-230).

\section{MATERIAL AND METHOD}

The dependent variable of this study was determined to be depression treatment period. The variable of depression treatment period was grouped under three categories as "1 year and less", "between 1-3 years" and "more than 3 years." As could be seen, multiple preference models were used in the analysis of the study because the categories of this variable had more than two statuses. In addition, due to its structure, the dependent variable was measured with an ordinal scale. Ordinal preference models have been used as the analysis method in such cases where the dependent variable was measured with an ordinal scale.

\section{Data Set}

In this study, the relationship between depression and the economy was tried to be investigated. For this purpose, a face-to-face questionnaire was performed to the patients diagnosed with depression using the Structured Clinical Interview Scale for DSM-IV (SCID-I) (Çorapçıoglu et al., 1999) by an experienced psychiatrist in Psychiatry Clinic of Binali Y1ldırım University Mengücek Gazi Training and Research Hospital. This questionnaire was administered to 311 depression patients (Yamane, 2010, s.49) in 2019-2020. While creating the variables in this study, "Race, Unemployment, and Mental Health in the USA: What Can We Infer About the Psychological Cost of the Great Recession Across Racial Groups?" carried out by Diette et al. in 2018 and "Inequality and the association between involuntary job loss and depressive symptoms" carried out Berchick et al. in 2012 were benefited.

In the study, the analyses were performed with Stata package software using the data set obtained from the questionnaires. Because logit and probit models were more useful in practice (Gujarati, 2004, p.582-583), the ordered 
probit model (Diette et al., 2018) was preferred due to its being easy in mathematical operations as the analysis method because the studies with similar subjects (Levecque et al., 2009; Doherty et al., 2008) offered differences due to frequently analyzing with logit model (Greene, 2002, p.667).

\section{Variables}

The variable of "depression treatment period" was used as the dependent variable in the econometric model created to determine the relationship between depression treatment period and economy. The variable of depression treatment period was grouped under three categories as " 1 year and less" (0), "between more than 1 year -3 years" (1) and "more than 3 years" (2).

On the other hand, the variables of gender, marital status, level of education, family type, assets, monthly income, period of employment, period of unemployment and expenditures out of disposable income that were considered to affect depression treatment period created the independent variables of the model: 
Investigating The Relationship Between Socio-Economic Characteristics...

\section{Table 1}

Independent Variables in the Model

\begin{tabular}{|c|c|c|}
\hline $\begin{array}{l}\text { Independent Variables } \\
\text { Name }\end{array}$ & Category & Reference Category \\
\hline Gender & $\begin{array}{l}\text { Male } \\
\text { Female }\end{array}$ & Male \\
\hline Marital status & $\begin{array}{l}\text { Married } \\
\text { Single } \\
\text { Other }\end{array}$ & Single \\
\hline Educational status & $\begin{array}{l}\text { Illiterate } \\
\text { Elementary school } \\
\text { Secondary/high school } \\
\text { Vocational school and } \\
\text { higher }\end{array}$ & Illiterate \\
\hline Family type & $\begin{array}{l}\text { Nuclear family } \\
\text { Extended family }\end{array}$ & Nuclear family \\
\hline Assets & $\begin{array}{l}\text { Yes } \\
\text { No }\end{array}$ & Yes \\
\hline Monthly income & $\begin{array}{l}2000 \text { TL and below } \\
\text { Between 2001-3000 TL } \\
\text { Between 3001-4000 TL } \\
\text { Between 4001-5000 TL } \\
\text { Between 5001-6000 TL } \\
6001 \text { TL and above }\end{array}$ & $2000 \mathrm{TL}$ and below \\
\hline Period of employment & $\begin{array}{l}\text { Never employed } \\
6 \text { years and less } \\
\text { Between more than } 6 \text { years } \\
-13 \text { years } \\
\text { Between more than } 13 \\
\text { years }-20 \text { years } \\
21 \text { years and more } \\
\text { Retired }\end{array}$ & Never employed \\
\hline Period of unemployment & $\begin{array}{l}\text { Not unemployed } \\
1 \text { year and less } \\
2 \text { years and more }\end{array}$ & Not unemployed \\
\hline $\begin{array}{l}\text { Expenditures out of disposable } \\
\text { income }\end{array}$ & $\begin{array}{l}\text { Yes } \\
\text { No } \\
\text { Partly }\end{array}$ & No \\
\hline
\end{tabular}




\section{FINDINGS OF THE STUDY}

\section{Descriptive Statistics}

According to Table 2, among the 311 participants who answered to the questionnaire, , $60 \%$ were female, $65 \%$ were married, $41 \%$ were secondary school/high school graduates, and $93 \%$ had a nuclear family type. Whereas $51 \%$ of the participants did not have any assets, $40 \%$ had monthly income between 2001-3000 TL. Whereas 37\% of the participants were employed for 6 years and less, $86 \%$ were not unemployed and $47 \%$ had expenditures out of disposable income.

\section{Table 2}

Descriptive Statistics

\begin{tabular}{llll}
\hline Variables & Categories & Frequency & Percentage \\
\hline \multirow{2}{*}{ Gender } & Male & 137 & 44.05 \\
& Female & 174 & 55.95 \\
Marital Status & Married & 202 & 64.95 \\
& Single & 89 & 28.62 \\
& Other & 20 & 6.43 \\
Educational Status & Illiterate & 11 & 3.54 \\
& Elementary school & 101 & 32.48 \\
& Secondary/high school & 128 & 41.16 \\
Family Type & Vocational school and higher & 71 & 22.83 \\
& Nuclear family & 288 & 92.60 \\
Assets & Extended family & 23 & 7.40 \\
& Yes & 151 & 48.55 \\
& No & 160 & 51.45 \\
Monthly Income & 2000 TL and below & 93 & 29.90 \\
& 2001-3000 TL & 114 & 36.65 \\
& 3001-4000 TL & 45 & 14.47 \\
& $4001-5000$ TL & 33 & 10.61 \\
& 5001-6000 TL & 7 & 2.26 \\
Feriod of & No01 TL and above & 19 & 6.11 \\
Employment & Never employed & 93 & 30.10 \\
& 6 years and less & 114 & 36.89 \\
Period of & Between more than 6 years -13 years & 45 & 14.56 \\
unemployment & Between more than 13 years -20 years & 32 & 10.36 \\
Expenditures out of & 21 years and more & 6 & 1.94 \\
disposable income & Retired & 19 & 6.15 \\
& Not unemployed & 268 & 86.18 \\
& 1 year and less & 16 & 5.14 \\
& Partly & 27 & 8.68 \\
& years and more & 85 & 27.33 \\
& & 146 & 46.95 \\
& & 80 & 25.72 \\
\hline
\end{tabular}


Investigating The Relationship Between Socio-Economic Characteristics...

\section{Testing Parallel Lines Assumption}

This model was based on the cumulative probabilities of the dependent variable categories and assumes that the regression functions were parallel for different dependent variable categories (Emeç, 2002, s.15). For this reason, this assumption must primarily be real in order to analyze with ordered probit model. The parallel lines assumption obtained from the prediction of ordered probit model was presented in Table 3 .

\section{Table 3}

Testing Parallel Lines Assumption

\begin{tabular}{lllc}
\hline & Chi-square value & Degree of freedom & Prob value \\
\hline Wolfe Gould & 25.87 & 22 & 0.257 \\
Brant & -12.54 & 22 & 1.000 \\
Score & 29.55 & 22 & 0.130 \\
Likelihood ratio & 38.18 & 22 & 0.017 \\
Wald & 24.02 & 22 & 0.346 \\
\hline
\end{tabular}

\section{Prediction Results of the Model}

The results assuming that the regression functions were parallel for different dependent variable categories and obtained from the ordered probit model based on the realization of this assumption were presented in table 4 .

According to the prediction results of ordered probit model, the variables of gender, educational status, family type, assets, monthly income and employment period had a statistically significant effect upon the period of depression treatment. In contrast, the variables of marital status, period of unemployment and expenditures out of disposable income were statistically insignificant upon period of depression treatment. Gender had a significant effect. In terms of educational status, it was especially significant for the participants graduated from secondary/high school and higher. It was also significant for the participants with a monthly income of 5001-6000 TL. It had a significant effect upon the participants employed for 21 years and more. 
Table 4

Ordered Probit Model

\begin{tabular}{|c|c|c|c|c|c|c|}
\hline Variable & Coefficient & $\begin{array}{l}\text { Std. } \\
\text { Deviation }\end{array}$ & Z Value & $\begin{array}{l}\text { Prob } \\
\text { Value }\end{array}$ & $\begin{array}{l}\% 95 \mathrm{Cc} \\
\text { Limits }\end{array}$ & fidence \\
\hline Gender & -0.396 & 0.169 & -2.34 & 0.019 & -0.728 & -0.064 \\
\hline \multicolumn{7}{|c|}{ Marital status (Reference category: Single) } \\
\hline Married & 0.190 & 0.212 & 0.90 & 0.370 & -0.225 & 0.604 \\
\hline Other & 0.559 & 0.349 & 1.60 & 0.109 & -0.125 & 1.242 \\
\hline \multicolumn{7}{|c|}{ Educational status (Reference category: Illiterate) } \\
\hline Elementary school & -0.511 & 0.397 & -1.29 & 0.198 & -1.290 & 0.267 \\
\hline $\begin{array}{l}\text { Secondary school / high } \\
\text { school }\end{array}$ & -0.878 & 0.401 & -2.19 & 0.029 & -1.663 & -0.092 \\
\hline $\begin{array}{l}\text { Vocational school and } \\
\text { higher }\end{array}$ & -1.387 & 0.446 & -3.11 & 0.002 & -2.262 & -0.513 \\
\hline Family type & -0.721 & 0.300 & -2.40 & 0.016 & -1.308 & -0.133 \\
\hline Assets & -0.400 & 0.157 & -2.54 & 0.011 & -0.709 & -0.092 \\
\hline \multicolumn{7}{|c|}{ Monthly income (Reference category: 2000 TL and below) } \\
\hline $2001-3000 \mathrm{TL}$ & 0.028 & 0.181 & 0.16 & 0.877 & 0.328 & 0.384 \\
\hline $3001-4000 \mathrm{TL}$ & -0.179 & 0.243 & -0.74 & 0.462 & -0.655 & 0.297 \\
\hline 4001-5000 TL & 0.147 & 0.287 & 0.51 & 0.610 & -0.417 & 0.710 \\
\hline $5001-6000 \mathrm{TL}$ & 1.121 & 0.566 & 1.98 & 0.048 & 0.011 & 2.231 \\
\hline $6001 \mathrm{TL}$ and above & -0.027 & 0.391 & -0.07 & 0.944 & -0.794 & 0.739 \\
\hline \multicolumn{7}{|c|}{ Period of employment (Reference category: Never employed) } \\
\hline 6 years and less & -0.101 & 0.254 & -0.40 & 0.691 & -0.599 & 0.397 \\
\hline $\begin{array}{l}\text { Between more than } 6 \\
\text { years }-13 \text { years }\end{array}$ & 0.007 & 0.369 & 0.02 & 0.985 & -0.717 & 0.730 \\
\hline $\begin{array}{l}\text { Between more than } 13 \\
\text { years }-20 \text { years }\end{array}$ & -0.203 & 0.286 & -0.71 & 0.477 & -0.764 & 0.357 \\
\hline 21 years and more & 0.626 & 0.313 & 2.00 & 0.046 & 0.012 & 1.240 \\
\hline Retired & 0.307 & 0.522 & 0.59 & 0.557 & 0.716 & 1.330 \\
\hline \multicolumn{7}{|c|}{ Period of unemployment (Reference category: Not unemployed) } \\
\hline 1 year and less & -0.241 & 0.349 & -0.69 & 0.490 & 0.925 & 0.443 \\
\hline 2 years and more & 0.345 & 0.279 & 1.24 & 0.215 & 0.201 & 0.892 \\
\hline \multicolumn{7}{|c|}{ Expenditures out of disposable income (Reference category: No) } \\
\hline Yes & -0.229 & 0.199 & -1.15 & 0.250 & 0.620 & 0.161 \\
\hline Partly & -0.187 & 0.181 & -1.03 & 0.302 & 0.542 & 0.168 \\
\hline
\end{tabular}

Summary information indicating the marginal effects were presented in table 5 . 
Investigating The Relationship Between Socio-Economic Characteristics...

Table 5

Marginal Effects

\begin{tabular}{|c|c|c|c|c|c|c|}
\hline \multirow[t]{2}{*}{ Variable } & \multicolumn{2}{|c|}{1 year and less } & \multicolumn{2}{|c|}{$\begin{array}{l}\text { Between more than } 1 \text { year - } \\
3 \text { years }\end{array}$} & \multicolumn{2}{|c|}{ More than 3 years } \\
\hline & $\mathrm{dy} / \mathrm{dx}$ & $\begin{array}{l}\text { Std. } \\
\text { Deviation }\end{array}$ & $\mathrm{dy} / \mathrm{dx}$ & $\begin{array}{l}\text { Std. } \\
\text { Deviation }\end{array}$ & $\mathrm{dy} / \mathrm{dx}$ & $\begin{array}{l}\text { Std. } \\
\text { Deviation }\end{array}$ \\
\hline Gender & $0.136 * *$ & 0.057 & $-0.032 * *$ & 0.014 & $-0.103 * *$ & 0.045 \\
\hline \multicolumn{7}{|c|}{ Marital status (Reference category: Single) } \\
\hline Married & -0.065 & 0.073 & 0.018 & 0.023 & 0.047 & 0.051 \\
\hline Other & -0.191 & 0.119 & $0.037 * * *$ & 0.022 & 0.154 & 0.104 \\
\hline \multicolumn{7}{|c|}{ Educational status (Reference category: Illiterate) } \\
\hline $\begin{array}{l}\text { Elementary } \\
\text { school }\end{array}$ & 0.166 & 0.116 & 0.009 & 0.028 & -0.175 & 0.140 \\
\hline $\begin{array}{l}\text { Secondary } \\
\text { school / high } \\
\text { school }\end{array}$ & $0.296^{*}$ & 0.117 & -0.018 & 0.030 & $-0.278 * *$ & 0.140 \\
\hline $\begin{array}{l}\text { Vocational } \\
\text { school and } \\
\text { higher }\end{array}$ & $0.467 *$ & 0.130 & $-0.086 * *$ & 0.042 & $-0.381 *$ & 0.142 \\
\hline Family type & $0.230 *$ & 0.085 & $-0.084 * *$ & 0.042 & $-0.146^{*}$ & 0.045 \\
\hline Assets & $0.138^{*}$ & 0.054 & $-0.035 * *$ & 0.015 & $-0.103^{*}$ & 0.040 \\
\hline \multicolumn{7}{|c|}{ Monthly income (Reference category: 2000 TL and below) } \\
\hline $2001-3000 \mathrm{TL}$ & -0.009 & 0.061 & 0.002 & 0.015 & 0.007 & 0.046 \\
\hline $3001-4000 \mathrm{TL}$ & 0.059 & 0.080 & -0.017 & 0.024 & -0.042 & 0.056 \\
\hline 4001-5000 TL & -0.049 & 0.096 & 0.011 & 0.019 & 0.039 & 0.077 \\
\hline 5001-6000 TL & $-0.339 * *$ & 0.134 & -0.011 & 0.054 & $0.350 * * *$ & 0.182 \\
\hline $\begin{array}{l}6001 \text { TL and } \\
\text { above }\end{array}$ & 0.009 & 0.131 & -0.002 & 0.034 & -0.007 & 0.097 \\
\hline \multicolumn{7}{|c|}{ Period of employment (Reference category: Never employed) } \\
\hline 6 years and less & 0.034 & 0.086 & -0.009 & 0.025 & -0.025 & 0.061 \\
\hline $\begin{array}{l}\text { Between more } \\
\text { than } 6 \text { years }-13 \\
\text { years }\end{array}$ & -0.002 & 0.126 & 0.000 & 0.032 & 0.002 & 0.095 \\
\hline $\begin{array}{l}\text { Between more } \\
\text { than } 13 \text { years - } \\
20 \text { years }\end{array}$ & 0.069 & 0.095 & -0.020 & 0.031 & -0.048 & 0.064 \\
\hline $\begin{array}{l}21 \text { years and } \\
\text { more }\end{array}$ & $-0.208 * *$ & 0.098 & $0.020 * * *$ & 0.011 & $0.188 * * *$ & 0.102 \\
\hline Retired & -0.104 & 0.175 & 0.019 & 0.019 & 0.086 & 0.157 \\
\hline \multicolumn{7}{|c|}{ Period of unemployment (Reference category: Not unemployed) } \\
\hline 1 year and less & 0.081 & 0.115 & -0.024 & 0.040 & -0.056 & 0.075 \\
\hline $\begin{array}{l}2 \text { years and } \\
\text { more }\end{array}$ & -0.117 & 0.093 & $0.019 * * *$ & 0.010 & 0.097 & 0.084 \\
\hline \multicolumn{7}{|c|}{ Expenditures out of disposable income (Reference category: No) } \\
\hline Yes & 0.077 & 0.067 & -0.019 & 18 & -0.058 & 0.049 \\
\hline Partly & 0.063 & 0.061 & -0.015 & .015 & -0.048 & 0.046 \\
\hline
\end{tabular}




\section{Depression treatment period for 1 year and less}

The females had depression treatment period of 1 year and less for $13.6 \%$ more than males. In other words, males had treatment for a longer period. And females responded to treatment in a shorter period. The participants with secondary/high school and higher graduation were $30 \%$ and $47 \%$ more likely to have a depression treatment period for 1 year and less rather than illiterate individuals. The period of treatment for depression decreased as the level of education increased. The illiterate individuals had a longer period of treatment for depression. People with extended family type were $23 \%$ more possible to have depression treatment period of 1 year and less rather than the individuals with a nuclear family. The participants with extended family type had longer depression treatment period. The participants with a nuclear family type had shorter treatment period for depression.

The participants with no assets were $14 \%$ more likely to have a depression treatment period of 1 year and less rather than the ones with assets. The individuals without assets had longer depression treatment period. The participants with a monthly income of 5001-6000 TL were 34\% less likely to have a depression treatment period of 1 year and less rather than the ones with a monthly income of $2000 \mathrm{TL}$ and less. The individuals with a higher monthly income had shorter treatment period for depression. And the participants with lower monthly income had depression treatment for a longer period. The participants employed for 21 years and more were $21 \%$ less likely to have a treatment period of 1 year and less for depression rather than the ones who were never employed. The participants who had never been employed had longer treatment period for depression. And the participants who were employed for 21 years and more had depression treatment for a shorter period.

\section{Depression treatment period for 1-3 years}

1-3-year treatment period for depression was 3\% less for females rather than males. In other words, the males had treatment for a longer period. And females had treatment for a shorter period. The participants with a marital status different from single and married (divorced) were 4\% more likely to have depression treatment period of 1 to 3 years rather than the ones with marital status of single. Treatment period of single and divorced participants for depression was longer. The participants with a vocational school and higher education level were 9\% less likely to have a depression treatment period of 1 to 3 years rather than illiterate people. The period of treatment for depression decreased as the level of education increased. The illiterate people had longer period of treatment for depression. 
Investigating The Relationship Between Socio-Economic Characteristics...

The participants with extended family were $8 \%$ less likely to have depression treatment period of 1 to 3 years when compared to the ones with a nuclear family. The participants with an extended family had shorter treatment period for depression. The individuals with a nuclear family type had longer depression treatment period. The participants with no assets were $3 \%$ less likely to have a depression treatment period of 1 to 3 years rather than the ones with assets. Depression treatment period was shorter for the participants who did not have any assets. The participants who were employed for 21 years and more were $20 \%$ more likely to have a depression treatment period of 1 to 3 years rather than the ones who had never been employed. The participants who were employed for 21 years and more had depression treatment for a longer period. The individuals who were never employed had shorter treatment period for depression.

According to the table, the participants who were unemployed for 2 years and more were $2 \%$ more likely to have a depression treatment period of 1 to 3 years rather than the ones who were employed. Unemployed participants had longer period of depression treatment.

\section{Depression treatment period for more than 3 years}

More than 3-year treatment period for depression was $10 \%$ less for females rather than the males. The females had shorter treatment period for depression. In other words, males had depression treatment for a longer period. The participants with educational status of secondary/high school and higher graduation were 28\% and $38 \%$ less likely to have a depression treatment period of more than 3 years when compared to illiterate ones. The period of treatment for depression decreased as the level of education increased. The illiterate participants had longer period of treatment for depression.

According to the table, the participants with extended family type were $15 \%$ less likely to have depression treatment for more than 3 years rather than the ones with nuclear family. The participants with extended family type had shorter treatment period for depression. The ones with a nuclear family type had longer depression treatment period. The participants with no assets were $10 \%$ less likely to have a depression treatment period of more than 3 years rather than the ones with assets. Depression treatment period of the participants without any assets was shorter. The participants with a monthly income of 5001-6000 TL were 35\% more likely to have a depression treatment period of more than 3 years rather than the ones with a monthly income of 2000 TL and less. The individuals with a higher monthly income had depression treatment for longer periods. The participants with lower monthly income had shorter depression treatment period. 
The participants who were employed for 21 years and more were $18 \%$ more likely to have a depression treatment period of more than 3 years rather than the ones who had never been employed. The participants who were employed for 21 years and more had longer depression treatment period. The ones who had never been employed had shorter treatment period for depression.

\section{DISCUSSION}

Depression is one of the most remarkable mental disorders individuals have experienced in recent years. The influence and period of depression affect human life negatively. Depression is affected by social and economic conditions of individuals. Socio-economic factors are highly efficient in etiology of mental health deterioration (Kosidou et al., 2011, p.160).

The presence of a strong relationship between individual socio-economic status and mental disorder has especially been observed. Although recent studies have been carried out on income inequality and mental health, no consistency has been noticed in their findings. It has been found that high income inequality creates an increased risk of depressive symptomatology on new mothers, and this relationship is highest among low-income people; however, inequality has been reported to be correlated with poor mental health among wealthy people (Gresenz et al., 2001, p.197-198).

Socio-economic status plays an important role for later psychological distress, but this relationship varies according to the extent or depth of socioeconomic status. Profession and education as the two most widely studied indicators appear to be weaker predictors of common mental disorders. Economic difficulties, unemployment and source of income have been accepted to be stronger predictors of common mental disorders. Cash margin interacts significantly with gender and is a determinant of psychological distress for females but not for males. In this sense, it is possible to be emphasized that regarding gender as well as measuring socio-economic status in various ways in public health research is important (Linander et al., 2014, p.235).

In terms of depression treatment period of 1 year and less; Depression treatment period is $13.6 \%$ longer for females than males. In other words, females have treatment for a longer period. The males responds to treatment in a shorter period. Gender differences in patterns associating mental health with health behaviors have also been documented in Europe. For example, females have tendency towards internalizing their emotions, and psychosomatic symptoms or mental health problems often appear dependently (Lazzarino et al., 2014, p.6). 
Investigating The Relationship Between Socio-Economic Characteristics...

Various studies have revealed the existence of social inequalities in mental health and psychological distress. It has been observed that more symptoms appear in less educated, unemployed, low-income groups and, less consistently, in lower occupational status groups. Furthermore, males and females are different in terms of the relationships between socio-demographic factors and psychological distress (Talala et al., 2007, p.24).

The period of depression treatment is $30 \%$ and $47 \%$ longer, respectively, for individuals with secondary/high school and higher graduation rather than the period for illiterate people. The higher the education level, the longer the depression treatment period. Depression treatment period of illiterate people is short. The individuals with a monthly income of 5001-6000 TL have 34\% less treatment period for depression rather than the ones with a monthly income of 2000 TL and less. Individuals with a high monthly income have shorter treatment period for depression, and individuals with a low monthly income have longer treatment period for depression. The individuals with no assets have $14 \%$ more depression treatment period rather the ones with assets. The individuals without assets have longer depression treatment period.

A study carried out in Wales has revealed that the individuals living in lowincome areas tend to have worse mental health status rather than the ones living in higher-income areas. Another study carried out in Denmark has reported that lower-income (lower third) participants have 3.5 times higher rates of minor depression and 8.5 times higher rates of major depression than those with higher incomes (Sugiyama et al., 2016, s.16). Socio-economic status and low income contribute upon negative outcomes restricting financial sources and higherpaying employment opportunities. Moreover, low socio-economic status and income are associated with mental health disorders such as depression due to the stress of living with less money than needed. There is clear evidence related to the fact that low socio-economic status and income are associated with weaker psychological and physical health outcomes, and more health problems are experienced with each step down the socio-economic status ladder. Indeed, the socio-economic status health gradient is the strongest for stress-sensitive diseases such as heart disease, diabetes, metabolic disorders and psychological disorders (Santiago et al., 2011, p.218-219).

Poor families' experiencing stressful life events in disproportionate numbers when compared to their middle-class counterparts makes stress an important proximate process that reveals the harmful effects of poverty. Such type of stress is associated with symptoms of depression, anxiety, hostility, and aggression among poor children and adolescents. Poverty is a cycle in which 
chronic stress factors continue be kept inside with little or no relief causing psychopathology. Moreover, psychopathology contributes upon this ongoing cycle making to manage stress factors more difficult or stressful (Santiago et al., 2011, p.219-220).

It has been argued that low socio-economic status is possible to be considered as an example of a chronic stress factor that increases exposure to acute stress factors and limits psycho-social resources to cope. It has also been suggested that low socio-economic status is possible to be considered as the 'root cause' of the disease beyond its effect on mediator mechanisms. What this and other studies have contributed is that the effects of objective measures of socioeconomic status such as income or professional social class upon mental health can be overestimated. If efficient ways to prevent and treat these disorders are to be designed, further researches are needed to be carried out for more subjective measurements of socio-economic status to improve understandability of the mechanisms that socio-economic conditions cause depression and anxiety (Skapinakis et al., 2006, p.116).

Therefore, in this study, measurements such as gender, marital status, education, employment period, unemployment period, expenditures out of disposable income, family type, and assets were analyzed besides socioeconomic measurements such as income and profession. The individuals with extended family type had $23 \%$ longer depression treatment period rather than the ones with nuclear family structure. The individuals employed for 21 years and more had $21 \%$ shorter treatment period for depression rather than the ones who were never employed. People were employed for 21 years and more had depression treatment for a shorter period. Depression treatment period of the never employed individuals was longer.

In terms of depression treatment period between 1-3 years; Depression treatment period of females was 3\% shorter rather than males. In other words, males had longer treatment. Females responded to treatment in a shorter period. The individuals with marital status different from single and married (divorced) had $4 \%$ longer treatment period for depression when compared to single individuals. Divorced people had longer depression treatment. The period of depression treatment was $9 \%$ shorter for individuals graduated from vocational school or higher rather than illiterate people. The period of treatment for depression decreased as the level of education increased. Illiterate individuals had long treatment period for depression. The individuals with extended family type had $8 \%$ shorter treatment period for depression rather than the ones with nuclear family structure. The individuals with extended family type had shorter treatment 
Investigating The Relationship Between Socio-Economic Characteristics...

period for depression. Depression treatment period of the individuals with a nuclear family type was longer.

The individuals with no assets had 3\% shorter treatment period for depression rather than the ones with assets. Depression treatment period was shorter for individuals who did not have any assets. The individuals who were employed for 21 years and more had $20 \%$ longer treatment period for depression rather than the ones who were never employed. The individuals who were never employed had shorter treatment period for depression. The participants who were employed for 21 years and more had longer depression treatment period. The individuals who were unemployed for 2 years and more were $2 \%$ more likely to have 1 to 3 years of depression treatment rather than those who were unemployed. Unemployed individuals had longer period of depression treatment. In terms of economic factors, the population-based studies (related to the unemployed) revealed that the individuals with relatively low income and/or low living standards were at higher risk of depression. The communities benefiting from advantageous social conditions were more possible to be relatively protected from negative mental health outcomes (Phongsavan et al., 2006, s.2546-2547).

Low socio-economic status was associated with a higher prevalence of depression. There was a clear relationship between worsening socio-economic conditions and depression (Lorant et al., 2007, s.293). There was substantial evidence related to a social gradient in the prevalence of common mental disorders including depression: Low socioeconomic status was associated with increased risk (Butterworth et al., 2009, s.229-230).

In terms of depression treatment period for more than 3 years; The females had $10 \%$ shorter depression treatment period rather than males. In other words, the males had treatment for longer. Depression treatment period for females was shorter.

The period of depression treatment was $28 \%$ and $38 \%$ shorter, respectively, for individuals graduated from secondary/high school and higher when compared to illiterate individuals. The period of treatment for depression decreased as the level of education increased. Illiterate individuals had longer treatment period for depression. The individuals with no assets had $10 \%$ shorter treatment period for depression rather than the ones with assets. Depression treatment period was shorter for individuals who did not have any assets.

The individuals with a monthly income of 5001-6000 TL had a 35\% longer depression treatment period rather than the ones with a monthly income of 2000 TL and less. The participants with low monthly income had shorter treatment 
period for depression. Those with a higher monthly income had longer depression treatment period.

A meta-analysis including more than 50 studies revealed that depression was inversely correlated with socioeconomic status defined with income or education level. It was concluded that individuals with lower social status were approximately 1.81 times more likely to report depression (Steptoe et al., 2007, s.97-98). Majority of previous studies indicated that people with lower socioeconomic status, as measured by parameters such as education and income level, had higher prevalence of psychological distress, and similar relationships were determined with the studies carried out on Japanese population. However, these findings also suggested that the relationship between socioeconomic status and psychological distress was possible to be complex. For example, males of high socioeconomic status were more vulnerable to interpersonal conflicts at work rather than males of low socioeconomic status. (Fukuda et al., 2011, s.11). This study revealed the negative effects upon the treatment period of people with high socio-economic status. People with extended family type had $15 \%$ shorter treatment time for depression than people with nuclear family structure. The people with extended family type had shorter treatment period for depression. And the ones with a nuclear family type had longer depression treatment period.

The individuals who were employed for 21 years and more had $18 \%$ longer treatment period for depression rather than the ones who were never employed. And the people who were never employed had shorter treatment period for depression. The individuals who were employed for 21 years and more had longer treatment period for depression.

\section{CONCLUSION}

The relationship between period of depression and socio-economic factors was explained in this study. The study was administered to the patients who were treated for depression for 1 year and less, 1 to 3 years, and more than 3 years. When considering the relationship between depression treatment period and socio-economic factors, inconsistencies were observed in period of treatment. When the depression treatment period was 1 year and less, depression treatment period of females took longer than males'. The period of treatment for depression increased as the level of education increased. Depression treatment period of illiterate individuals was shorter. The people with high monthly income had shorter treatment period for depression, and the ones with low monthly income had longer depression treatment period. Moreover, the individuals without assets 
Investigating The Relationship Between Socio-Economic Characteristics...

had longer depression treatment period. The people with extended family type had longer depression treatment period rather than the ones with nuclear family. The individuals who were employed for 21 years and more had depression treatment for a shorter period. Depression treatment period of the people were never employed was longer.

The results were the same in patients treated for depression for 1 to 3 years and for more than 3 years. The period of treatment for females was shorter than males in permanent depression that lasted for years. The period of treatment for depression was shorter as the level of education increased. The patients with high monthly income had longer treatment periods rather than the ones with low monthly income. The period of treatment was shorter in patients with extended families. The period of treatment was shorter in patients who did not have any assets (house, land, car, vineyard, garden, field, etc.). Depression treatment period was longer in patients who were employed for 21 years and more rather than in patients who were never employed.

In summary, the variables of age, gender, educational status, marital status, family type, assets, monthly income, employment period, etc. in the findings obtained in the study were in parallel with the literature. On the other hand, if the field research could be carried out in a province similar to Erzincan in the east in terms of population and geographical characteristics, it would be highly likely to reveal different findings and the study would be more meaningful. However, the pandemic process did not allow such a study to be conducted. Therefore, two different regions could not be compared.

\section{REFERENCES}

Allen, J., Balfour, R., Bell, R. \& Marmot, M. (2014). Social determinants of mental health. International Review of Psychiatry, 26(4), 392-407.

Amemeya, T. (1984), Tobit models: a survey. Journal of Econometrics, 24, 3561.

Berchick, R. E., William T. Gallo, W.T., Maralani, V. \& Kasl, S.V. (2012). Inequality and the association between involuntary job loss and depressive symptoms. Social Science \& Medicine, 75, 891-1894.

Butterworth, P., Rodgers, B. \& Windsor, T. D. (2009). Financial hardship, socioeconomic position and depression: Results from the PATH Through Life Survey. Social Science \& Medicine, 69, 229-237. 
Çorapçıoglu A, Aydemir Ö, Yıldız M, Esen Danacı A. \& Köoglu E. (1999). DSMIV Eksen I Bozuklukları (SCID-I) için Yapılandırılmış Klinik Görüşme, Klinik Versiyon. Hekimler Yayın Birliği.

Diette, T.M., Goldsmith, A.H., Hamilton, D. \& Darity, W. (2018). Race, unemployment, and mental health in the USA: What can we infer about the psychological cost of the great recession across racial groups? Journal of Economics, Race and Policy, 75-91.

Doherty, D.T., Moran, R. \& Kartalova-O'Doherty, Y. (2008). Psychological distress, mental health problems and use of health services in Ireland. Health Research Board.

Emeç, H. (2002). Ege bölgesi tüketim harcamalari için sirali logit tahminleri ve senaryo sonuçlari. Dokuz Eylül Üniversitesi Sosyal Bilimler Enstitüsü Dergisi, 4(2), 13-29.

Frijters, P., Johnston, D.W. \& Shields, M.A. (2014). The effect of mental health on employment: evidence from Australian panel data. Health Economics, 23, 1058-1071.

Freeman, A., Tyrovolas, S., Koyanagi, A. et al. (2016). The role of socioeconomic status in depression: Results from the COURAGE (aging survey in Europe). BMC Public Health, 16, 1-8.

Fukuda, Y. \& Hiyoshi, A. (2012). Influences of income and employment on psychological distress and depression treatment in Japanese adults. Environ Health Prev Med, 17, 10-19.

Greene, W. H. (2002). Econometric Analysis. Prentice Hall.

Gresenz, C.R., Sturm, R. \& Tang, L. (2001). Income and mental health: Unraveling community and individual level relationships. The Journal of Mental Health Policy and Economics, 4, 97-203.

Gujarati, D. N. (2004). Basic Econometrics. The McGraw-Hill Companies.

Kosidou, K., Dalman, C., Lundberg, M., Hallqvist, J., Isacsson, G. \& Magnusson, C. (2011). Socioeconomic status and risk of psychological distress and depression in the Stockholm public health cohort: A population-based study. Journal of Affective Disorders, 134, 60-167.

Lazzarino, A.I., Yiengprugsawan, V., Seubsman, Sa. et al. (2014). The associations between unhealthy behaviours, mental stress, and low socioeconomic status in an international comparison of representative samples from Thailand and England. Globalization and Health, 10, 1-8. 
Investigating The Relationship Between Socio-Economic Characteristics...

Levecque, K., Lodewyckx, I. \& Bracke, P. (2009). Psychological distress, depression and generalised anxiety in Turkish and Moroccan immigrants in Belgium A general population study. Social Psychiatry and Psychiatr Epidemiol, 44, 188-197.

Linander, I., Hammarström, A. \& Johansson, K. (2015). Which socio-economic measures are associated with psychological distress for men and women? A cohort analysis. European Journal of Public Health, 25(2), 31-236.

Lorant, V., Croux, C., Weich, S., Deliège, D., Mackenbach, J., \& Ansseau, M. (2007). Depression and socio-economic risk factors: 7-year longitudinal population study. British Journal of Psychiatry, 190(4), 293-298.

Phongsavan, P., Chey, T., Bauman, A., Brooks, R. \& Silove, D. (2006). Social capital, socio-economic status and psychological distress among Australian adults. Social Science Medicine, 63(10), 2546-2561.

Santiago, C., Wadsworth, M. \& Stump, J. (2011). Socioeconomic status, neighborhood disadvantage and poverty-related stress: Longitudinal effects on psychological syndromes among diverse low-income families. Journal of Economic Psychology, 32(2), 218-230.

Skapinakis, P., Weich, S., Lewis, G., Singleton, N. \& Araya, R. (2006). Socioeconomic position and common mental disorders: Longitudinal study in the general population in the UK. British Journal of Psychiatry, 189(2), 109-117.

Steptoe, A., Tsuda, A., Tanaka, Y. \& Wardle, J. (2007). Depressive symptoms, socio-economic background, sense of control, and cultural factors in university students from 23 countries. International Journal of Behavioral Medicine, 14, 97-107.

Sugiyama, T., Leslie, E., Giles-Corti, B., Owen, N. (2008). Associations of neighbourhood greenness with physical and mental health. Health \& Place, 38, 16-21.

Talala, K., Huurre, T., Aro, H., Martelin, T. and Prattala, R. (2008). Socio demographic differences in self-reported psychological distress among 25to 64-year-old Finns. Social Indicators Research, 86, 323-335

WHO (2017). Mental health atlas. World Health Organization.

Yamane, T. (2010). Temel Örnekleme Yöntemleri, (Çev. Alptekin Esin). Literatür Yayınc1lik. 


\section{INTERNET RESOURCES}

WHO (2021). https://www.who.int/home/search?indexCatalogue=generic searchindex $1 \&$ searchQuery=depression. Access date: 01.11.2021

\section{EXTENDED ABSTRACT}

Purpose: The purpose of this study was to investigate the relationship between socio-economic characteristics and period of depression treatment in patients diagnosed with depression in Erzincan.

Method: Face-to-face questionnaire was performed to the patients diagnosed with depression in the Psychiatry Clinic of Erzincan Binali Yıldırım University Mengücek Gazi Training and Research Hospital. This questionnaire was performed to 311 patients diagnosed with depression. The analysis was performed using ordered probit model. For the questionnaire, 26.12.2019 dated and 12/18 protocol numbered "Human Research Ethics Committee" approval was obtained from Erzincan Binali Yıldırım University.

Findings: The duration for the treatment was shorter in female patients treated for depression for more than 3 years rather than males. The duration of treatment for depression decreased as the level of education increased. The patients with higher monthly income had longer treatment periods rather than the ones with lower monthly income. The duration of treatment was shorter in patients with extended families. The duration of treatment was shorter in patients who had no assets. The period for depression treatment was longer in patients who worked for 21 years and more rather than the ones who had never been employed. These findings were totally opposite for the treatment period of 1 year and less.

Conclusion: The relationship between period of depression and socio-economic factors was explained in this study. The study was administered to the patients who were treated for depression for 1 year and less, 1 to 3 years, and more than 3 years. When considering the relationship between depression treatment period and socio-economic factors, inconsistencies were observed in period of treatment.

When the depression treatment period was 1 year and less, depression treatment period of females took longer than males'. The period of treatment for depression increased as the level of education increased. Depression treatment period of illiterate individuals was shorter. The people with high monthly income had shorter treatment period for depression, and the ones with low monthly 
Investigating The Relationship Between Socio-Economic Characteristics...

income had longer depression treatment period. Moreover, the individuals without assets had longer depression treatment period.

The people with extended family type had longer depression treatment period rather than the ones with nuclear family. The individuals who were employed for 21 years and more had depression treatment for a shorter period. Depression treatment period of the people were never employed was longer.

The results were the same in patients treated for depression for 1 to 3 years and for more than 3 years. The period of treatment for females was shorter than males in permanent depression that lasted for years. The period of treatment for depression was shorter as the level of education increased. The patients with high monthly income had longer treatment periods rather than the ones with low monthly income. The period of treatment was shorter in patients with extended families. The period of treatment was shorter in patients who did not have any assets (house, land, car, vineyard, garden, field, etc.). Depression treatment period was longer in patients who were employed for 21 years and more rather than in patients who were never employed.

In summary, the variables of age, gender, educational status, marital status, family type, assets, monthly income, employment period, etc. in the findings obtained in the study were in parallel with the literature. On the other hand, if the field research could be carried out in a province similar to Erzincan in the east in terms of population and geographical characteristics, it would be highly likely to reveal different findings and the study would be more meaningful. However, the pandemic process did not allow such a study to be conducted. Therefore, two different regions could not be compared. 